\title{
NEW WORLD
}

\section{Power, Pollution and Politics}

from our New York Correspondent

Mayor JoHn Lindsay has now settled for an uneasy eompromise, hedged about with all kinds of promises for the future, in the dispute between the City and Consolidated Edison, the utility company supplying metropolitan New York with power. The annual summer power crisis has this year been punctuated by arguments about the application by ConEd to install 1,600 MW of generating capacity at Astoria in Queens, a stretch of industrial wilderness alongside the Triborough Bridge long since abandoned to power stations. Mr Lindsay announced on Saturday last week that he would let the utility company install just half the generating capacity for which it had asked, and enough on the mayor's calculation to assure base-load supplies for the city until 1974. In its agreement with the city, ConEd has also agreed to use natural gas at the new plant if it can obtain supplies, but otherwise low-sulphur petroleum, to push ahead with plans for building nuclear plants, to abandon coal-burning altogether, to import more power by transmission line from outside New York City, to scrub the gases from the new plants and never again to ask for permission for new fossilfuelled generating capacity. Mr Lindsay may seem to the conservationists to have caved in to ConEd, but if he can hang on he may yet emerge as the man who outlawed fossil fuels from New York.

The long struggle between the environmentalists and ConEd, in which the mayor has sought perhaps unwisely to hold the ring, is not now at an end. There is still dispute about a proposal to build a pumped storage station on the Hudson at a beauty-spot called Storm King Mountain, and although the Federal Power Commission endorsed last week its own earlier decision that the building of that plant could go ahead, there are likely to be scveral obstacles in ConEd's path before that project can begin. Unlike the Astoria project, Storm King Mountain is intended as a source of power to meet the peak demand for electricity. It was first suggested in the early sixties, but even then evoked protests that the Hudson had been sufficiently despoiled already.

In the battle over the Astoria plant, the environmentalists have been led by $\mathrm{Mr}$ Jerome Kretchmer, the Environmental Protection Commissioner for New York. ConEd estimates that by 1974 the peak power need for New York will be more than nine million kilowatts, increasing to nearly ten million by 1975 . With 1,600 MW from Astoria it would be able to generate 12.5 million kilowatts by 1974 and another 800,000 by 1975 . This would give the city 36 per cent reserve above the projected peak in 1974. ConEd claims that this large reserve is necessary because of the high likelihood of failure in one or more plants. Already this summer two generating plants have failed, reducing capacity by 17 per cent.

$\mathrm{Mr}$ Kretchmer and others refused to accept ConEd's arguments, noting that the Federal Power Commission considers reserves of 20 to 25 per cent to be ample. $\mathrm{Mr}$ Kretchmer argues that other power sites are available, but that ConEd does not want to spend the extra money needed to bring the power into the city. He also believes that ConEd could continue to meet any shortages by bringing in power from other utilities, but ConEd responds that other utilities are also facing possible shortages and cannot guarantee any supply to New York beyond 1972.

The chief support for the opposition, however, centres on the dangerous level of air pollution in the city. Astoria is recognized as the most polluted area in the country, and New York itself in recent years has far outdistanced Los Angeles in terms of smog and air pollution. While cars are now considered the major source of air pollution, power plants are not far behind. ConEd claims that the modern plant at Astoria would meet all Federal, state and city health and environment standards; because it also would be replacing older facilities it would in effect decrease the total amount of air pollution in the city. $\mathrm{Un}$ fortunately, this will not help the residents of Astoria.

Mr Lindsay's plea that ConEd should use natural gas at Astoria if only supplies can be found is an attempt to reduce the emission of sulphur dioxide and smoke, but there is now such a grave shortage of natural gas that ConEd recently joined with a number of conservation groups in petitioning the Federal Government for a larger supply of natural gas to meet the present needs. In any case, both gas and oil present health hazards. Mr Kretchmer estimates that between 1,000 and 2,000 people die prematurely in New York City each year from sulphur dioxide poisoning; and even if Astoria used low-sulphur oil the plant would add about 15,000 tons of sulphur dioxide to the air annually according to $\mathrm{Mr}$ Kretchmer.

Natural gas also has its snags, chiefly that it produces nitrogen oxide, a cause of smog. At a symposium last week sponsored by the Citizens for Clean Air Dr Carl Shy, an epidemiologist at the National Air Pollution Control Administration, estimated that the nitrogen oxide from the Astoria plant would cost society between $\$ 250,000$ and $\$ 750,000$ a year, the cost of increased respiratory illness among the local residents.

Whatever the truth, the debate has amply demonstrated that power has never been properly planned in the eity. The Astoria plant appears to be an in. adequate, and probably dangerous, solution to the present crisis, but the philosophy behind it is even more questionable. Until recently it was assumed that the city, like the rest of the country, could continue to expand simply by increasing all inputs. But services in the city have begun to disintegrate in recent years, possibly through poor administration. but certainly through overloading and strain. The problem facing Mayor Lindsay and ConEd should not be how to provide more power, but how to use what is available more efficiently. The way things are going, the need for more power will certainly disappear as more people desert the city for the still somewhat clean air of the suburbs. 